DOI: $10.20472 / E F C .2018 .010 .018$

\author{
JAKŠA KRIŠTO \\ University of Zagreb Faculty of Economics and Business, Croatia \\ ALEN STOJANOVIĆ \\ University of Zagreb Faculty of Economics and Business, Croatia \\ AUGUST CESAREC \\ University of Zagreb Faculty of Economics and Business, Croatia
}

\title{
COMPARISON OF ECONOMIC DEVELOPMENT AND BANKING LOAN ACTIVITIES ON A CASE OF CROATIAN COUNTIES
}

\begin{abstract}
:
Banking credit policy is an important pillar of the economic development of a country as well as countries narrower territorial units. Regional development is often based on comprehensive government and municipal policy, geographical and demographic characteristics, statistical classification, a role of different government agencies but also of a financial institutions business policy. The goal of this paper is to compare level of economic development with a banking loan activities in case of Croatian counties. The paper is analysing banking loan activities based on loan to deposit ratio, relative size of banking loan activities on a county level as well as currency and type of a loan structure of banking loan portfolio. Indicators of banking loan activities are compared with counties economic development using non-hierarchical k-means cluster analysis. Research in a paper is looking for an answer to what extent are seen similarities of economic development of Croatian counties and total banking loan activities. In this sense paper is comparing two methodologies, regional development measurement and characteristics of banking loan business.
\end{abstract}

\section{Keywords:}

regional development, banking loans, regional financial intermediation, counties, Croatia

JEL Classification: G21, 016, R10 


\section{Introduction}

Croatia is regionally very heterogenic country from the perspective of demographic and geographic characteristics as well as from the level of economic development. Counties in Croatia, as NUTS3 regional municipal units, are territorial units in this research. Regional disparities between counties have various reasons and indicators. In this research, level of the economic development of a county is compared with the characteristics of a total banking loan activities. Research question in this paper is how similar are clusters of counties by the criteria of economic development on the one hand and banking loan activities on the other hand. The paper is analysing banking loan activities through different indicators such as loan to deposit ratio, relative size of banking loan activities on a county level as well as currency and type of a loan structure of banking loan portfolio. Clusters of counties by economic development are based on regional development classification of counties in Croatia. Indicators of banking loan activities are compared with counties economic development using non-hierarchical k-means cluster analysis. Research in based on a hypothesis that clusters of counties based on criteria of economic development and banking loan activities are different. This impose comparison of two methodologies in this paper, regional development measurement and characteristics of banking loan business.

Financial system and financial intermediation of financial institutions is unavoidableof economic development because of the important function that the financial sector is providing through efficient asset allocation and transmission of financial assets.Different authors were questioning greater efficiency of one of the types of financial system market-based or bank-based or irrelevance of type of financial system for economic growth (see Stojanović, Krišto, 2016).

The role of money and financial system in the regional economy has been attracting increasing attention. It has been a topic of interest for longer in the US literature, reflecting the regional concerns of a federal state. European financial integration and more general political changes have raised the importance of the topic for Europe (Dow Rodríguez-Fuentes, 1997). Authors in this field, among other questions, were discussing the impact of a financial intermediation on economic growth on an example of regions of different countries. They underline that such an analysis is more relevant, since regional data are more homogeneous, the regulatory and legal frameworks are the same and the financial systems are clearly defined and implemented. Research confirm a positive relationship of the depth of bank intermediation or banking competition and regional growth(Carbo et al., 2003;Guiso et al., 2004; Valverdeet al., 2007). A geographically decentralized financial system with sizable and wellembedded regional/local clusters of institutions, networks, agents, and markets could be advantageous in various ways. Regional/local capital markets also face a number of major challenges and problems(Klagge, Martin, 2005). The question of influence of banking profitability and economic growth is also pronounced (Pasiouras, Kosmidou, 2007; Dietrich,Wanzenried, 2011; Hasan, et al., 2007; Klein, Weill, 2017). Issue of regional development and banking loans could be seen also from the perspective of 
banking loans as one of the sources of financing. According to ECB, bank-related products remained the most relevant source of financing for SMEs compared with market-based instruments and other sources of financing. From October 2017 to March 2018, just over half of euro area SMEs considered bank loans and credit lines to be relevant financial instruments for their businesses. Around $45 \%$ of SMEs interviewed stated that bank loans are not a relevant source of financing for them. In the vast majority of these cases, SMEs had no need for financing via a bank loan (73\%) (ECB, 2018).

Some other authors suggest that banks can nevertheless influence regional development through credit availability (Rodriguez-Fuentes, 1998). Monetary policy and financial institutions have an active role in an uneven regional development. Uneven regional development is the consequence of a series of economic policies and influences, including money and bank intermediation (Dow, 1987).

Limited number of research in Croatia regarding regional financial intermediation has been conducted. Available research is analysing characteristics of banking intermediation over the counties in Croatia (Kristo, Mandac, 2015), regional business policy of insurance companies (Kristo, 2014) and characteristics of banking credit policy over the Croatian counties (Kristo, Tuskan, 2016). Above mentioned research indicated high level of centralization in banking assets in the City of Zagreb as a financial centre and an outlier comparing to other counties in Croatia. Demographic, rural and economic characteristics of a counties are seen in a structure of a banking credit portfolio. Counties are rather heterogeneous regarding characteristics of banking intermediation although some of them are rather consistent over the counties e.g. level of euroization.Less developed counties are characterized by higher share of consumer loans, overdrafts and loans denominated in Croatian Kuna's. Developed counties are seeing higher share of mortgages and CHF denominated loans. This paper is step further in analysis of influence of financial intermediation on regional development in Croatia as an example of small, open and less developed economy.

Article is organised according to IMRAD approach. In an introduction goal and hypothesis of a paper are presented together with literature review. The second chapter is explaining regional division and the level of development of a counties in Croatia, as well as, key characteristics of banking sector in Croatia and regional characteristics of banking intermediation. Third chapter is presenting data and research methodology followed by results and discussion. In a conclusion research outcome is summarised together with research limitations and recommendations for future research.

\section{Regional development and banking sector inCroatia}

Croatia is organised in 20 Counties and the City of Zagreb (NUTS 3 level) as a separate territorial unit (Act on territories of counties, towns and municipalities in the Republic of Croatia, Act on City of Zagreb). According to regulatory framework (Act on Regional Development of the Republic of Croatia, 2017; Regulation on Development Index, 2017; Decision on classification of local and regional self-government units 
according to development level, 2017), counties in Croatia are divided according to index of development in four groups. This categorisation allows them to have equal approach to regional development policy. According to this methodology, five counties (City of Zagreb, Istarska, Dubrovačko-neretvanska, Zagrebačka and Primorskogoranska) are in the group of most developed counties, four in the second group (Zadarska, Splitsko-dalmatinska, Varaždinska, Međimurska) in third six (Krapinskozagorska, Koprivničko-križevačka, Šibensko-kninska, Osječko-baranjska, Karlovačka and Požeško-slavonska) and in least developed group six counties (Brodskoposavska, Bjelovarsko-bilogorska, Ličko-senjska, Vukovarsko-srijemska, Sisačkomoslavačka and Virovitičko-podravska) (MRRFEU, 2018). Methodology behind development index is based on composite index of following indicators: (1) rate of unemployment, (2) income per capita, (3) budget income of municipality per capita, (4) population migration, (5) rate or education and (6) index of ageing (Regulation on Development Index, 2017). Counties in third and fourth development group - least development counties have the status of supported counties according to regulatory framework and regional development strategy in Croatia (Strategy of Regional Development of Republic of Croatia for period until 2020). Regional development strategy is based on fulfilment of three strategic goals: increasing the quality of life by supporting sustainable regional development, increasing competitiveness of regional economy and employment and comprehensive management of regional development.

The Croatian financial sector, as in most European countries, is a type of bank-based financial system, where banks hold almost $70 \%$ of the assets of the financial sector. Additionally, banks are major or partial owners of other key financial intermediaries, e.g.management companies of investment funds or pension funds andleasing companies. In the period 2004-2016, the ratio of banking assets to GDP ranged from $91 \%$ in the 2004 to $111 \%$ in 2016 , achieving biggest ratio of $122 \%$ in 2011 . The growth of the ratio until 2011 is a consequence of the sharp increase in the assets of the banking sector of $77 \%$ from 2004 , which is more than double of the growth of the GDP (33\%). From 2011 onwards, the assets of the banking sector have decreased slightly by $5 \%$.

Taking into account the banks' balance sheets, the banking sector indicators are demonstrating signs of the traditional banking sector business model with loans and deposits as key assets and liabilities (64\% and 70\%; 2004-2016). On a market level, banks show high level of capital adequacy. Banking credit policy is one of the key prerequisites for the success of banks' efficiency, especially loans to households and non-financial corporations, two sectors with highest percentage of given loans $(43 \%$ and 32\% in 2016) (Croatian National Bank, 2018).

The number of banks is demonstrating decreasing trend (from 39 in 2004 to 24 in 2015), mostly due to the "exit" from the market or acquisition of small banks. Thus, the concentration of the banking sector is increasing in the recent years, with the assets of the top five banks accounting $75 \%$ of total bank assets (Croatian National Bank, 2017). These biggest banks are all foreign owned, Italian or Austrian ownership prevailing, and, despite similar number of banks in domestic and foreign ownership, 
almost $90 \%$ of the banking sector assets is foreign owned.Banks' profitability in showing decreasing trend, achieving values below $10 \%$ and $1 \%$ for ROA and ROE respectively in recent years, comparing to pre-crisis levels. In 2015 banks experienced loss in amount of 5.03 billion Kuna's due to conversion of loans in Swiss francs into loans in euro (Croatian National Bank, 2017).

Regarding regional characteristics, strong economic and regional importance of the Croatian capital the City of Zagreb, considered as a separate county in Croatia, is also evident in the banking sector data by counties. Headquarters of the most banks, especially big banks, are located in Zagreb, hence it is not surprising that highest percentage of banking assets $(58 \%)$ and banking assets per capita $(\sim 260,000 \mathrm{kn})$ is achieved in country capital (Figure 1). Beside Zagreb, only two counties (Splitskodalmatinska and Primorsko-goranskacounty) have share of banking assets higher than $5 \%$, while second county by assets per capita, Primorsko-goranska county, has slightly over $1 / 3$ of the banking assets per capitaachieved in Zagreb.

\section{Figure 1: Banks'indicators by counties (2010-2015, average values)*}

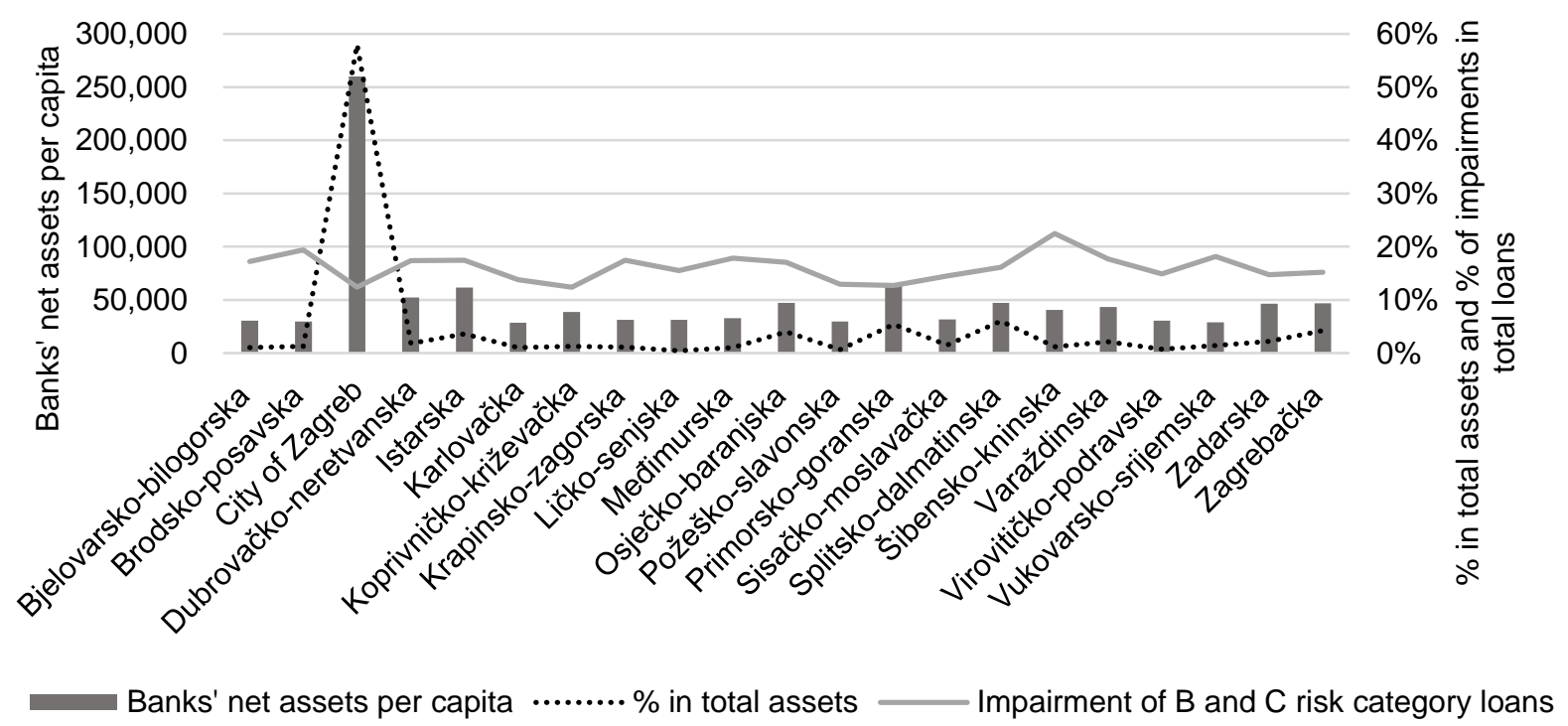

* Data for assets and loans refer to counterparties from Republic of Croatia with headquarters or residence in county.

Source: Author's calculation according to the received data from the Croatian National Bank

Analysis and calculation of more specific banking indicators further demonstrate severe differences between counties. This is shown not just by financial indicators, but also by geographic distribution of branches, ranging from only 7 to 30 banks represented in different counties. Interestingly, ratio of bank assets to GDP is higher than 1 only in City of Zagreb, which is also having percentage of loans to households of only $26.64 \%$, well below other counties. This can be explained by amount of loans to state and public institutions, whose headquarters are mostly in Zagreb thus consisting higher loan percentage in specified county. 
Table 1. Banks' indicators by counties (2010-2015, average values) ${ }^{*}$

\begin{tabular}{|l|r|r|r|r|r|}
\hline \multicolumn{1}{|c|}{ County } & $\begin{array}{c}\text { Banks with } \\
\text { branch in } \\
\text { county* }\end{array}$ & $\begin{array}{c}\text { Bank } \\
\text { assets/GDP* } \\
*\end{array}$ & $\begin{array}{c}\text { Bank } \\
\text { loans/deposits* } \\
*\end{array}$ & $\begin{array}{c}\text { \% of foreign } \\
\text { currency } \\
\text { loans }\end{array}$ & $\begin{array}{c}\text { \% of loans } \\
\text { to } \\
\text { households }\end{array}$ \\
\hline Bjelovarsko-bilogorska & 11 & 0.58 & 1.24 & 68.12 & 63.58 \\
\hline Brodsko-posavska & 13 & 0.67 & 1.33 & 70.43 & 64.87 \\
\hline City of Zagreb & - & 1.86 & 1.35 & 75.73 & 26.64 \\
\hline Dubrovačko-neretvanska & 13 & 0.68 & 0.80 & 77.65 & 63.92 \\
\hline Istarska & 18 & 0.63 & 0.77 & 76.99 & 57.46 \\
\hline Karlovačka & 11 & 0.50 & 0.87 & 67.21 & 72.42 \\
\hline Koprivničko-križevačka & 12 & 0.58 & 1.47 & 64.95 & 54.54 \\
\hline Krapinsko-zagorska & 8 & 0.65 & 1.31 & 64.65 & 68.32 \\
\hline Ličko-senjska & 7 & 0.52 & 0.86 & 74.59 & 70.84 \\
\hline Međimurska & 12 & 0.51 & 0.88 & 68.75 & 62.27 \\
\hline Osječko-baranjska & 17 & 0.76 & 1.82 & 69.83 & 53.13 \\
\hline Požeško-slavonska & 13 & 0.65 & 1.22 & 71.89 & 64.31 \\
\hline Primorsko-goranska & 23 & 0.68 & 0.91 & 75.22 & 54.55 \\
\hline Sisačko-moslavačka & 11 & 0.53 & 1.65 & 63.12 & 72.46 \\
\hline Splitsko-dalmatinska & 20 & 0.78 & 0.84 & 75.30 & 50.09 \\
\hline Šibensko-kninska & 12 & 0.67 & 0.86 & 75.69 & 49.97 \\
\hline Varaždinska & 16 & 0.68 & 1.43 & 69.10 & 53.16 \\
\hline Virovitičko-podravska & 11 & 0.67 & 1.46 & 65.94 & 58.82 \\
\hline Vukovarsko-srijemska & 13 & 0.63 & 1.58 & 65.34 & 62.57 \\
\hline Zadarska & 18 & 0.74 & 0.88 & 75.72 & 59.31 \\
\hline Zagrebačka & 30 & 0.79 & 1.21 & 69.89 & 69.96 \\
\hline
\end{tabular}

* Data for assets and loans refer to counterparties from Republic of Croatia with headquarters or residence in county.

${ }^{* *}$ Data for City of Zagreb are included in the data of Zagrebačkacounty

Source: Author's calculation according to the received data from the Croatian National Bank and data from the Croatian Bureau of Statistics

All counties have higher percentage of foreign than domestic currency loans and this indicator is showing smallest variation between all counties. Regarding ratio of bank loans to deposits, 12 counties have indicator higher than 1, thus having relatively higher financial leverage, while for 9 counties indicator is lower than 1. Interestingly, all coastal counties have this ratio lower than 1 due to geographical and economic characteristics.

\section{Data and methodology}

The data for this analysis is retrieved from the multiple sources. Publicly available publications and databases from the National Bureau of Statistics were used to retrieve economic data. Since banks' data on the county levels are not publicly available, this data were retrieved based on the written inquiry to the Croatian National Bank for the period 2010-2015.All indicators were calculated based on these initial data sources, with MS Office Excel used for descriptive statistics and SPSS for cluster analysis. Six key indicators were used to conduct cluster analysis: 
- loan to deposit ratio,

- loans per capita,

- share of impairments of B and C risk category loans in total loans,

- share of mortgage loans in total household loans,

- share of general-purpose cash loans in total household loans and

- share of monthly household loans per capita in monthly salary.

All indicatorswere calculated separately for all 20 counties and the City of Zagreb. Indicators represent average value of that indicator for period from 2010 to 2015.

Initial analysis by counties demonstrated significant difference between counties for most banks' indicators. In order to determine similar groups taking into account economic and bank indicators cluster analysis was used. It is a technique which analyses data sets to assess whether they can be placed into small number of clusters (groups) which resemble each other and are different from units in other clusters (Everitt et al., 2011). Two main algorithms to identify affiliation to certain cluster are hierarchical and non-hierarchical algorithms. In a hierarchical classification, the data are not partitioned into a particular number of clusters at a single step and the classification consists of a series of partitions, which may run from a single cluster with all individuals to $n$ clusters with a single individual (Everitt et al., 2011). On the other hand, non-hierarchical algorithms classify data into $k$ groups, where $k$ is given by the user, and there are at most as many groups as there are objects (Kaufman, Rousseeuw, 2009).

In this model, k-means method of non-hierarchical clustering is used to put up counties into clusters. The main aim of the technique is to simplify data by representing them with $K$ centroids rather than the original $n$ entities (Hennig et al., 2015). After centroids are obtained for each cluster, objects are compared to each centroid and moved to the cluster whose centroid is closest, new centroids are then recalculated after all objects have been assigned and method finishes when no object can be moved between clusters (Steinley, 2006).

Due to the fact that development index as a measure of economic development is differentiating counties in four groups, the same number of clusters is predefined in kmeans method of non-hierarchical clustering. Prior to analysis standardization of variables was conducted using the standardized " $z$ " value.

\section{Results and discussion}

Results of non-hierarchical k-means cluster analysis based on 6 indicators representing characteristics of banking loan activitiesindicate the significance of all indicators at significance level of $5 \%$, except share of impairments of $B$ and $C$ risk category loans in total loans. 
Table 2. Cluster membership of non-hierarchical k-means cluster analysis based on 6 indicators of banking loan activities

\begin{tabular}{|l|l|l|l|}
\hline \multicolumn{1}{|c|}{ Cluster 4 } & \multicolumn{1}{|c|}{ Cluster3 } & \multicolumn{1}{c|}{ Cluster2 } & \multicolumn{1}{c|}{ Cluster1 } \\
\hline 1. Grad Zagreb & $\begin{array}{l}\text { 1. Dubrovačko- } \\
\text { neretvanska, }\end{array}$ & $\begin{array}{l}\text { 1. Brodsko-posavska } \\
\text { 2. Osječko-baranjska }\end{array}$ & $\begin{array}{l}\text { 1. Bjelovarsko- } \\
\text { bilogorska }\end{array}$ \\
& $\begin{array}{l}\text { 2. Istarska } \\
\text { 3. Međimurska }\end{array}$ & $\begin{array}{l}\text { 3. Varaždinskažupanija } \\
\text { 4. Virovitičko-podravska }\end{array}$ & $\begin{array}{l}\text { 3. Korlovačka } \\
\text { 3riževačka }\end{array}$ \\
& 4. Primorsko-goranska & 5. Vukovarsko-srijemska & 4. Krapinsko-zagorska \\
& 5. Splitsko-dalmatinska & & 5. Ličko-senjska \\
& 6. Zadarska & & 6. Požeško-slavonska \\
& 7. Zagrebačka & & 7. Sisačko-moslavačka \\
& & & 8. Šibensko-kninska \\
\hline
\end{tabular}

Source: Authors calculations using SPSS

The highest contributors to clustering solution, according to ANOVA table (indicator with the highest F-ratio) are loans per capita, share of mortgage loans in total household loans and share of general-purpose cash loans in total household loans.

Table 3. ANOVA table of non-hierarchical k-means cluster analysis based on 6 indicators of banking credit portfolio

\begin{tabular}{|c|c|c|c|c|c|c|}
\hline & \multicolumn{2}{|c|}{ Cluster } & \multicolumn{2}{|c|}{ Error } & \multirow{2}{*}{$\mathrm{F}$} & \multirow[b]{2}{*}{ Sig. } \\
\hline & Mean Square & $\mathrm{df}$ & Mean Square & $\mathrm{df}$ & & \\
\hline Loan to deposit ratio & 3.956 & 3 & 0.537 & 17 & 7.366 & 0.002 \\
\hline Loans per capita & 6.536 & 3 & 0.082 & 17 & 79.758 & 0.000 \\
\hline $\begin{array}{l}\text { Share of impairments of } B \\
\text { and } C \text { risk category loans in } \\
\text { total loans }\end{array}$ & 1.270 & 3 & 1.011 & 17 & 1.257 & 0.321 \\
\hline $\begin{array}{l}\text { Share of mortgage loans in } \\
\text { total household loans }\end{array}$ & 5.153 & 3 & 0.326 & 17 & 15.805 & 0.000 \\
\hline $\begin{array}{l}\text { Share of general-purpose } \\
\text { cash loans in total } \\
\text { household loans }\end{array}$ & 4.452 & 3 & 0.450 & 17 & 9.901 & 0.001 \\
\hline $\begin{array}{l}\text { Share of monthly household } \\
\text { loans per capita in monthly } \\
\text { salary }\end{array}$ & 4.035 & 3 & 0.523 & 17 & 7.712 & 0.002 \\
\hline
\end{tabular}

Source: Authors calculations using SPSS

Cluster membershipaccording to non-hierarchical k-means cluster analysis of banking indicators based on predefined number of clusters (4) variates from the level of economic development of a county represented through cluster-groups based on development index. Differences could be seen in a case of two groups of developed counties as well as in a groups of less developed counties. The City of Zagreb again stood as a separate cluster due to the fact that the City of Zagreb is financial centre and most of the bank headquarters are located there. The biggest difference 
comparing to economic development is seen in this cluster where most of the counties of Adriatic region also form this cluster.

Table 4. Groups of counties according to development index

\begin{tabular}{|c|c|c|c|}
\hline $\begin{array}{l}\text { Most developed } \\
\text { counties }\end{array}$ & Developed counties & $\begin{array}{l}\text { Less developed } \\
\text { counties }\end{array}$ & $\begin{array}{l}\text { Least developed } \\
\text { counties }\end{array}$ \\
\hline $\begin{array}{l}\text { 1. Grad Zagreb } \\
\text { 2. Istarska } \\
\text { 3. Dubrovačko- } \\
\text { neretvanska, } \\
\text { 4. Zagrebačka } \\
\text { 5. Primorsko- } \\
\text { goranska }\end{array}$ & $\begin{array}{l}\text { 1. Zadarska } \\
\text { 2. Splitsko-dalmatinska } \\
\text { 3. Varaždinska } \\
\text { 4. Međimurska }\end{array}$ & $\begin{array}{l}\text { 1. Krapinsko-zagorska } \\
\text { 2. Koprivničko- } \\
\text { križevačka } \\
\text { 3. Šibensko-kninska } \\
\text { 4. Osječko-baranjska } \\
\text { 5. Karlovačka } \\
\text { 6. Požeško-slavonska }\end{array}$ & $\begin{array}{l}\text { 1. Brodsko-posavska } \\
\text { 2. Bjelovarsko- } \\
\text { bilogorska } \\
\text { 3. Ličko-senjska } \\
\text { 4. Vukovarsko- } \\
\text { srijemska } \\
\text { 5. Sisačko-moslavačka } \\
\text { 6. Virovitičko-podravska }\end{array}$ \\
\hline
\end{tabular}

Source: According to MRRFEU (2018)

Clusters of economically less developed counties and also clusters of less developed banking credit characteristics shows also non-similarities. Taking a more throw insight into data, it appears that less develop counties regarding banking loan activities are characterised with lower level of financial leverage of households based on share of monthly household loans per capita in monthly salary, lower share of mortgage loans in total household loans and therefore higher level of cash loans in total household loans. It could be concluded that economically less developed and rural counties are characterised bylower quality of banking loan portfolio. Indicator of loan to deposit ratio is higher in less developed counties. In this sense it is providing more of an information about lower level of savings in these counties than the banking excessive credit granting of households having in mind financial leverage of households based on share of monthly household loans per capita in monthly salary. Relative indicators of corporate credits needs to be taken in consideration here as well.

\section{Conclusion}

Obtained results in this analysis again point to regional differences and diversities in Croatia. Official methodology for evaluating development of a counties based on development index shows quite different results when compared to characteristics of banking loan activities. Research in this paper is not questioning mutual influences of banking loan policy on economic development of a county or vice versa. That important question is beyond the scope of this research. Results of this paper are however pointing to quite substation level of differentiation between these two methodologies. Large disparities between the development of the City of Zagreb and the rest of the country are well detected in clusters according to banking loan activities. Having in mind the importance of financial sector and banking credit in achieving even economic growth and therefore regional development this results should be taken into consideration. The economic capacity of a county and characteristics of banking loan activities can open a question about market potential of local financial institutions whose business policy would be adjusted to regional specifies of a county/counties. It is necessary to include data about regional financial 
intermediation into framing regional development strategy because banks, as mostly privately owned financial institutions, should however contribute to even regional development. In this way, government strategic incentives and policy for financial sector in a part of tax incentives and the role of development banks and other sources of financing should be encouraged. It is important to emphasise that population migrations and depopulation from less developed counties are also putting a pressure on economic development and also on banking loan portfolio. Households loans as a dominate form of lending will, due to demographic trend in less developed counties, not gain needed importance. Limited statistical data on regional finance is disadvantage for conducting this kind of research. More precise and granular data are needed. Future research in this field could be oriented on influence of banking loans on efficiency of corporate sector, detail analysis of influence of regional financial intermediation on regional development as well as questions if regional banking strategy and perspectives for development of smaller regional banks or credit unions.

\section{References}

Act on City of Zagreb, Official Gazzete, No. 62/01, 125/08, 36/09 and 119/14.

Act on Regional Development of the Republic of Croatia, Official Gazzete, No. 147/14 and123/17.

Act on territories of counties, towns and municipalities in the Republic of Croatia, Official Gazzete, No. 86/06, 125/06, 16/07, 95/08, 46/10, 145/10, 37/13, 44/13, 45/13 and 110/15.

Carbo, S., Humphrey, D. and Rodriguez Fernandez, F. (2003) Deregulation, bank competition and regional growth, Regional Studies, Vol.37, No. 3,pp.227-237.

Croatian National Bank (2017) Banks bulletin, No. 30, Croatian National Bank, Zagreb.

Croatian National Bank (2018) Prudential data on credit institutions - tables. Available on: https://www.hnb.hr/en/statistics/statistical-data/financial-sector/other-monetary-financialinstitutions/credit-institutions/indicators-of-credit-institution-operations

ECB (2018) Survey on the Access to Finance of Enterprises in the euro area October 2017 to March 2018. Available on: https://www.ecb.europa.eu/stats/ecb surveys/safe/html/index.en.html

Decision on classification of local and regional self-government units according to development level, Official Gazzete, No. 132/17.

Dietrich, A. andWanzenried, G. (2011). Determinants of bank profitability before and during the crisis: Evidence from Switzerland,Journal of International Financial Markets, Institutions and Money, Vol. 21, No. 3,pp. 307-327.

Dow, S.C. (1987). Money and Regional Development,Studies in Political Economy, Vol. 23, pp. 73-94.

Everitt, B.S., Landau, S., Leese, M. and Stahl, D. (2011) Cluster analysis, $5^{\text {th }}$ ed., John Wiley and Sons, Hoboken.

Government of the Republic of Croatia (2017) Strategy of Regional Development of Republic of Croatia for period until 2020, Government of the Republic of Croatia, Zagreb.

Guiso, L., Sapienza, P. and Zingales, L. (2004) Does Local Financial Development Matter?,The Quarterly Journal of Economics, Vol. 119, No. 3, pp. 929-969.

Hasan, I., Koetter, M. andWedow, M. (2007). The quality of banking and regional growth. Bundes Bank Series 2 Discussion paper, No. 10/2007, Deutsche Bundesbank, Frankfurt am Main

Hennig, C., Meila, M., Murtagh, F. and Rocci, R. (2015) Handbook of cluster analysis, CRC Press, Boca Raton. 
Kaufman, L. and Rousseeuw, P. J. (2009). Finding groups in data: an introduction to cluster analysis, John Wiley and Sons, Hoboken.

Klagge, B. and Martin, R. (2005) Decentralized versus centralized financial systems: is there a case for local capital markets?,Journal of Economic Geography, Vol. 5, No. 4, pp. 387-421.

Klein, P. O. and Weill, L. (2017). Bank Profitability: Good for Growth?,Working Papers of LaRGEReseachCenter, No. 2017-02,Laboratoire de RechercheenGestion et Economie (LaRGE), Université de Strasbourg.

Krišto, J. (2014) Regional specificities of Croatia and market potential of insurers, in Ćorić, S. et al., Proceedings of international scientific-expert conference Croatian insurance days 2014, Croatian Chamber of Economy, Zagreb, $5^{\text {th }}-7^{\text {th }}$ November 2014, pp.105-118.

Krišto, J. andMandac, I. (2015) Characteristics of bank financial intermediation in Croatian counties, Financial Theory \& Practice, Vol. 39, No. 1, pp. 57-82.

Krišto, J. andTuškan, B. (2016) Characteristics of Bank's Credit Policy According to Counties in the Republic of Croatia, Ekonomija, Vol. 22, No. 2, pp. 315-333.

MRRFEU (2018) Values of development index and indicators for calculation of development indexfor counties (period 2014-2017), Available at: https://razvoj.gov.hr/o-ministarstvu/djelokrug1939/regionalni-razvoj/indeks-razvijenosti/vrijednosti-indeksa-razvijenosti-i-pokazatelja-zaizracun-indeksa-razvijenosti-2018/3740

Pasiouras, F. and Kosmidou, K. (2007) Factors influencing the profitability of domestic and foreign commercial banks in the European Union, Research in International Business and Finance, Vol. 21, No. 2,pp. 222-237.

Regulation on Development Index, Official Gazzete, No. 131/17

Rodríguez-Fuentes, C. J. (1998), Credit availability and regional development,Papers in Regional Science, Vol. 77, No. 1,pp. 63-75.

Dow, S.C. andRodríguez-Fuentes, C.J. (1997) Regional Finance: A Survey, Regional Studies, Vol.31, No. 9,pp.903-920.

Steinley, D. (2006)K-means clustering: A half-century synthesis,British Journal of Mathematical and Statistical Psychology, Vol. 59, No. 1, pp.1-34.

Stojanović, A. andKrišto, J. (2016). Efficiency of the financial system structure and development of Capital market union, in Stojanović,A. and Šimović, H. (eds.), Contemporary problems and challenges in financial sector development, University of Zagreb Faculty of Economics and Business, Zagreb, pp. 3-22.

Valverde, S. C., López Del Paso, R. and Rodríguez Fernández, F. (2007). Financial innovations in banking: Impact on regional growth, Regional Studies, Vol. 41, No. 3,pp. 311-326. 